\title{
Influence of Groundnut and Machine Characteristics on Motorised Sheller Performance
}

\author{
Wangette Isaac S., Nyaanga Daudi M., Njue Musa R. \\ Department of Agricultural Engineering, Egerton University, Njoro, Kenya
}

Email address:

wangettesi@yahoo.com (Wangette, I. S.), dmnyaanga@gmail.com (Nyaanga, D. M), musanjue@yahoo.com (Njue, R. M)

To cite this article:

Wangette, I. S., Nyaanga, D. M., Njue, R. M. Influence of Groundnut and Machine Characteristics on Motorised Sheller Performance. American Journal of Agriculture and Forestry. Vol. 3, No. 5, 2015, pp. 178-191. doi: 10.11648/j.ajaf.20150305.13

\begin{abstract}
Groundnut shelling is a fundamental process in post-harvest management. Manual shelling is inefficient and laborious with low throughput. Motorised shellers experience less than $100 \%$ shelling efficiency and varying levels of kernel damage. From the research, throughput per unit power consumption and shelling efficiency increased with reduction in $\%$ moisture content (mc), with maximum outputs realized at $6 \%$. Kernel mechanical damage decreased with increase in $\%$ mc up to a minimum at between $15 \%$ and $18 \%$ mc then increased marginally with further rise in mc. Meanwhile, throughput per unit power consumption increased with bulk density of the groundnut variety being shelled. In addition, kernel to pod diameter ratio had a significant influence on the outputs under study. All the three output parameters under review rose exponentially with increase in feed rate. Throughput per unit power consumption and shelling efficiency rose steadily with increase in shelling speed with the highest values obtained at a shelling speed of about $12 \mathrm{~m} / \mathrm{s}$. Kernel mechanical damage remained low (less than 4\%) for speeds below $8 \mathrm{~m} / \mathrm{s}$, and then rose sharply with further increment in speed. All the output parameters increased with reduction in concave clearance with maximum values obtained at $10 \mathrm{~mm}$ clearance. Steel and rubber paddles yielded the highest throughput per unit power consumption. At low shelling speeds (less than $8 \mathrm{~m} / \mathrm{s}$ ), rolling rubber and steel pipes resulted in lowest shelling efficiency and kernel mechanical damage but at higher speeds they resulted into both highest shelling efficiency and kernel mechanical damage.
\end{abstract}

Keywords: Groundnut Sheller, Input Characteristics, Taguchi DOE, S/N Ratio, Optimization, Sheller Performance

\section{Introduction}

\subsection{Background Information}

Groundnut (Arachis hypogaea) is the sixth most important oil crop in the world (Ikechukwu et al., 2014). The major groundnut producing countries include India, China, Nigeria, Senegal, Sudan, Burma and the United States of America, with a world average yield of 1.4 metric tonnes per hectare (t/ha) (Madhusudhana, 2013). Shelling of groundnuts is a fundamental process as it allows the kernel and hull to be available for use. It constitutes about $38 \%$ of postharvest costs (Butts et al., 2009). Traditional shelling methods have been found to be inefficient, laborious, time consuming and result in low output (Gitau et al., 2013). Hence, there is need for motorised shellers. Abubakar and Abdulkadir (2012) categorized factors that affect groundnut shellers into three types. First are machine based that include cylinder speed, concave clearance and fan speed. Next are crop factors such as moisture content, size and orientation. Last are operational based factors like feed rate and operator's skill and experience. Performance of groundnut shellers is evaluated by determining the effect of these characteristics on some measurable dependent variables. The most often used parameters include throughput, shelling efficiency, winnowing or cleaning efficiency and mechanical damage.

Studies to determine optimum operating conditions for shellers have been done using different designs of and varied results have been obtained. Gamal et al (2009) investigated the effect of moisture content on groundnut maximum stress, deformation and toughness. Helmy et al (2007) modified a rotary sheller into a reciprocating one and determined optimum shelling speed and feed rate as $1.4 \mathrm{~m} / \mathrm{s}$ and $160 \mathrm{~kg} / \mathrm{h}$ respectively. Adedeji and Ajuebor (2002) determined the best shelling speed, concave clearance and feed rate for a motorised groundnut sheller and Oluwole et al (2007) evaluated the influence of moisture content, impeller angulation and impeller slots on performance of a centrifugal Bambara groundnut sheller. There has been limited research work on comprehensive groundnut sheller performance that 
involves the combined influence of four or more machine, nut and operational factors. Research involving many factors and levels lead to large numbers of experimental runs that result into high costs and is time consuming. In addition, using a one factor at a- time method when dealing with several variables fails to consider any possible factor interactions, hence it is less efficient than other methods based on statistical approach to design (Ballal et al., 2012).

\subsection{Statement of the Problem}

Challenges in groundnut shelling include tedious and time consuming methods among manual shellers; to kernel damage and incomplete shelling in motorised types. Current performance evaluation of groundnut shellers is based on machine throughput; shelling and winnowing efficiencies and kernel mechanical damage. At present a key factor to consider in machine operations is its rate of energy use, determined by considering the machine power consumption against its throughput. Research data on power consumption in groundnut shellers is limited. Hence, a gap exists in the evaluation of groundnut sheller performance. Research on nut moisture content required for optimum shelling performance has yielded varying results, with values of 5\%, $13 \%$ and $15 \%$ being suggested (Adedeji and Ajuebor, 2002; Akcali et al., 2006; and Nyaanga et al., 2007). Results from concave clearance tests recommend differing optimum values of $12 \mathrm{~mm}, 18 \mathrm{~mm}$ and $30 \mathrm{~mm}$ (Adedeji and Ajuebor, 2002; Helmy et al., 2007 and Rostami et al., 2009). This indicates inconsistence in recommendations for both moisture content levels and concave clearance for optimum shelling. In addition, information on influence of shelling blades on performance in groundnut shellers is limited.

\subsection{Objectives}

1. To determine the influence of groundnut moisture content, variety and feed rate on throughput per unit power consumption, shelling efficiency and kernel mechanical damage in a motorised sheller.
2. To determine the influence of concave clearance, shelling speed and shelling blade type on throughput unit power consumption, shelling efficiency and kernel mechanical damage in a motorised sheller.

\subsection{Research Questions}

1. What is the influence of groundnut moisture content, variety and feed rate on throughput per unit power consumption, shelling efficiency and kernel mechanical damage in a motorised sheller?

2. What is the influence of concave clearance, shelling speed and shelling blade type on throughput per unit power consumption, shelling efficiency and kernel mechanical damage in a motorised sheller?

\section{Literature Review}

\subsection{Groundnut Characteristics}

The major groundnut characteristics are their morphology, physical and mechanical properties like cracking stress, moisture content, variety, size dimensions, coefficient of friction and angle of repose. Physical properties of seeds in machine design are recognized as important parameters to be determined along with the machine parameters. They are useful in solving many of the problems associated with machine design and also in analysis of the behavior of products during agricultural processing. Dimensions such as geometric mean diameter, arithmetic mean diameter, aspect ratio and sphericity describe the size and shape of the seed which influence its behavior such as flowability (Amoah, 2012).

\subsubsection{Variety}

Studies on groundnut physical properties of various varieties have been carried out and their findings published. Examination of some physical properties of Turkish groundnut varieties yielded results in Table 2.1.

Table 2.1. Physical properties of Turkish groundnuts.

\begin{tabular}{|c|c|c|c|c|c|}
\hline $\begin{array}{l}\text { Kernel solid density } \\
\left(\mathrm{g} / \mathrm{cm}^{3}\right)\end{array}$ & $\begin{array}{l}\text { Shell solid density } \\
\left(\mathrm{g} / \mathrm{cm}^{3}\right)\end{array}$ & $\begin{array}{l}\text { Kernel bulk density } \\
\left(\mathrm{g} / \mathrm{cm}^{3}\right)\end{array}$ & $\begin{array}{l}\text { Shell bulk density } \\
\left(\mathrm{g} / \mathrm{cm}^{3}\right)\end{array}$ & $\begin{array}{l}\text { Angle of } \\
\text { repose }\end{array}$ & $\begin{array}{l}\text { Coefficient of } \\
\text { friction }\end{array}$ \\
\hline $0.88-0.93$ & $0.27-0.30$ & $0.54-0.59$ & $0.066-0.077$ & $29^{0}$ & $0.23-0.76$ \\
\hline
\end{tabular}

Source: Akcali et al. (2006)

Akcali et al. (2006) determined the size of groundnuts by measuring their principal axial dimensions. The average major, intermediate and minor diameters of kernels were found to be $8.54 \mathrm{~mm}, 6.93 \mathrm{~mm}$ and $3.55 \mathrm{~mm}$ respectively. Angle of repose of kernels on wooden surface was found to be $17^{0}$. Characteristics of two groundnut varieties used in an experiment had average measurements as given in Table 2.2.

Table 2.2. Physical properties of two groundnut varieties.

\begin{tabular}{llllll}
\hline Variety & $\begin{array}{l}\text { Pod diameter } \\
(\mathbf{m m})\end{array}$ & Pod length $(\mathbf{m m})$ & $\begin{array}{l}\text { Kernel diameter } \\
(\mathbf{m m})\end{array}$ & $\begin{array}{l}\text { Kernel weight } \\
(\mathbf{g})\end{array}$ & Moisture content of pods at shelling (\%) \\
\hline Manipinta (Red) & 12.6 & 31.9 & 7.8 & 1.4 & $12-22$ \\
Chinese (White) & 11.6 & 26.3 & 7.5 & 1.0 & $12-28$ \\
\hline
\end{tabular}

Source: Bobobee (2002) 
Table 2.3. Physical properties of ICRISAT groundnut varieties in Kenya.

\begin{tabular}{lllllll}
\hline & $\begin{array}{l}\text { Axial Dimensional } \\
\text { length }(\mathbf{m m})\end{array}$ & $\begin{array}{l}\text { Major diameter } \\
(\mathbf{m m})\end{array}$ & $\begin{array}{l}\text { Minor diameter } \\
(\mathbf{m m})\end{array}$ & Bulk density $\left(\mathbf{k g} / \mathbf{m}^{\mathbf{3}}\right)$ & $\mathbf{1 0 0 0}$ pod weight $(\mathbf{g})$ & $\begin{array}{l}\text { Angle of } \\
\text { repose }\left({ }^{0}\right)\end{array}$ \\
\hline Maximum range & $25.10-34.55$ & $12.85-15.90$ & $11.65-13.50$ & $760.40-680.70$ & $572.10-591.40$ & $36-32$ \\
Minimum range & $14.95-16.05$ & $8.65-10.65$ & $8.55-8.85$ & $508.50-410.60$ & $560.90-569.30$ & $26-25$ \\
\hline
\end{tabular}

Source: Gitau et al. (2013)

A study by Gitau et al. (2013) on the physical characteristics of groundnut varieties developed by the International Crops Research Institute for the Semi-Arid Tropics (ICRISAT) in Kenya yielded results as shown in Table 2.3 .

Results from the same research indicated that large sized varieties resulted in higher shelling efficiencies than their small sized counterparts for the same concave clearance and feed rate.

\subsubsection{Moisture Content}

Moisture content of seed refers to the amount of water contained in the seed (Amoah, 2012). According to Armitage and Wontner (2008), too moist cereals and oilseeds can be subject to mould growth and mycotoxin production, mite infestations and sprouting. Conversely, over-dried grain before or during storage can result in splitting and cracking, low quality and wastage in energy utilization. As such, moisture content of grain is one of the most important parameters considered when deciding the quality and prize of grain at the stage of harvesting, storage, processing and marketing (Rai et al., 2005).

Gitau et al. (2013) showed that shelling efficiency increased with decrease in moisture content for all groundnut varieties studied. Gamal et al. (2009) found out that increase in moisture content leads to an increase in the major, minor and intermediate diameters of groundnut kernel. Results from experiments for Bambara nuts indicated that moisture content had higher effect on performance than feed rate. Thus, percentage seed damage increases with increase in moisture content while shelling efficiency decreases with increase in moisture content (Atiku et al., 2004). Nyaanga et al. (2007) gave a probable explanation of the effect; that as the moisture content increases, the efficiency decreases since the pods become friable, tending to flex instead of cracking and breaking hence leading to a higher percentage of unshelled groundnuts.

The value of optimum moisture content for shelling varies across researchers. Gitau et al. (2013); and Akcali et al. (2006) gave a figure of 5\% while Nyaanga et al. (2007); and Adedeji and Ajuebor (2002) proposed $13 \%$ and $10-15 \%$ respectively (unless specified, all moisture contents are expressed on a wet basis). Moisture conditioning can be carried out to obtain different desired levels of moisture contents. The formula employed in the process according to Gamal et al. (2009) is as follows:

$$
Q=\frac{W_{i}\left(M_{f}-M_{i}\right)}{\left(100-M_{f}\right)}
$$

Where;
$Q=$ Mass of water to be added $(\mathrm{kg})$

$W_{i}=$ Initial mass of the sample $(\mathrm{kg})$

$M_{i}=$ Initial moisture content of the sample (\%)

$M_{f}=$ Final or desired moisture content of the sample (\%)

Experiments on choice of moisture content for optimum shelling have been carried out in this research in a bid to breach the gap between varying results.

\subsubsection{Feed Rate}

Nyaanga et al. (2007) determined that feed rate increased with concave clearance. This was explained by the fact that the bigger the opening in the chamber the more pods that can be shelled per revolution. Trials on a manual sheller showed that in both rubber tyre and wood paddle shellers, feed rate of between $50-100 \mathrm{~kg} / \mathrm{hr}$ at an average of $75 \mathrm{rpm}$ does not significantly affect shelling performance (Chinsuwan, 1983). According to Amodu (2012), energy consumption in soy bean and cowpeas threshing is directly proportional to feed rate and tip cylinder speed irrespective of concave clearance. In the case of castor oil, shelling capacity, here referred to as mass flow rate, was found to increase with increase in cylinder speed (Balami et al., 2012).

The determination of influence of groundnut feed rate on power consumption, shelling efficiency and kernel damage was part of this research work.

\subsection{Machine Characteristics}

\subsubsection{Concave Clearance}

A decrease in concave clearance leads to an increase in shelling efficiency and kernel damage. While this general trend was observed by all researchers on the subject, their values of concave clearance for optimum shelling were different. Nyaanga et al. (2007) observed that the efficiency of the sheller increases from $73.6 \%$ at concave clearance of 20 $\mathrm{mm}$ to a peak of $79.8 \%$ at $30 \mathrm{~mm}$ then decreases to $73.2 \%$ at $40 \mathrm{~mm}$ clearance. Experiments in Thailand showed that shelling efficiencies and kernel damage decrease with increase in clearance. Clearances of between $7 \mathrm{~mm}$ to $15 \mathrm{~mm}$ were used in a TPI sheller for Taina and other groundnut varieties local to Thailand (Chinsuwan, 1983). Less damage could be obtained with a larger clearance but shelling efficiency would be substantially decreased. The same conclusions were reached by Rostami et al. (2009), who observed that shelling efficiency decreased as clearance increased and damage rapidly decreased as clearance increased from 8 to $12 \mathrm{~mm}$ and gradually decreased as clearance increased from 12 to $20 \mathrm{~mm}$. Helmy et al. (2007) concluded that the optimum shelling efficiency of $95.44 \%$ at a feed rate of $80 \mathrm{~kg} / \mathrm{h}$ could be obtained with a clearance of $18 \mathrm{~mm}$, while Adedeji and Ajuebor (2002), gave a range of $30 \mathrm{~mm}-40 \mathrm{~mm}$. Bobobee 
(2002) while working on a variable speed motor arrived at a concave clearance of 16-18 $\mathrm{mm}$ at 180-220 rpm.

In this work further research has been conducted to determine concave clearances that result in optimal sheller power consumption, shelling efficiency and kernel mechanical damage.

\subsubsection{Type of Sieve}

There are two types of sieves in common use, namely; the wire mesh sieve and the slotted grate sieve. The sieve size is chosen depending on the size of groundnuts to be shelled. The wire mesh size used in the experiments for manual shellers in Thailand was $11 \mathrm{~mm}$ by $11 \mathrm{~mm}$ (Chinsuwan, 1983). In the development of a groundnut sheller with a capacity of $35 \mathrm{~kg} / \mathrm{h}$, a concave made of round steel bars of $5 \mathrm{~mm}$ diameter was employed (Park et al., 1990). Helmy et al. (2007) concluded that the performance of the wire mesh sieve was better than the slotted grate as shown in Table 2.4.

Table 2.4. Comparison of effects of sieve type on shelling.

\begin{tabular}{llll}
\hline Type of concave sieve & Shelling capacity $(\mathbf{k g} / \mathbf{h})$ & Shelling efficiency $(\%)$ & Percentage breakage $(\%)$ \\
\hline Wire mesh & 86 & $83-89$ & $3.7-6.7$ \\
Slotted grate & 60 & $82-84$ & $8.4-12.6$ \\
\hline
\end{tabular}

Source: Helmy et al. (2007)

\subsubsection{Type of Shelling Blades}

Groundnut pods are shelled when they get embedded in the space between shelling blades and the concave sieve where they are acted upon by shearing, impact or, frictional forces either singly or in combination with each other. The characteristics of the blades that most likely affect shelling performance include; their material type, shape and the number mounted on the cylinder. Helmy et al. (2007) found out that the shelling efficiency, using rubber covered drum was less than that of both steel and wooden drum. For shellers utilizing paddles, kernel damage due to wood paddles was found to be substantially less than that due to rubber covered paddles, while the difference in shelling efficiency was relatively small (Chinsuwan, 1983). Gitau et al. (2013) determined that shelling efficiency was higher in steel rod beater shellers than wooden beater shellers. As far as the number of beaters is concerned, Helmy et al. (2007) determined that an increase in number of drum beaters from 4 to 8 increased shelling efficiency at low drum speeds of 1.83 $\mathrm{m} / \mathrm{s}$ and $4.58 \mathrm{~m} / \mathrm{s}$. Studies by Kamboj et al. (2012) on pea shelling, employing L-shaped blades to provide maximum rubbing action, resulted in minimum kernel damage compared to that by both impact and shearing actions. Centrifugal impellers or rollers rotating in counter directions are utilized in shelling kernels with hard pods or coats such as Bambara nuts (Siebenmorgan et al., 2006). Research on the influence of various shapes of blades on shelling performance of groundnuts has been included in this work.

\subsubsection{Shelling Speed}

Nyaanga et al. (2007) observed that shelling efficiency increased to a maximum with increase in speed but decreased with further increase in speed. Rostami et al. (2009) concluded that shelling efficiency increased with speed but had no significant effect on kernel damage. This agrees with results obtained from performance evaluation on a Prosopis africana pod thresher which showed that threshing efficiency and seed loss increased with increase in cylinder speed and fan speed (Ishola, 2011). Amodu (2012) found out that though visible grain damage to groundnut kernels at high speeds may be below $5 \%$, internal damage to the grains could be very high as determined by germination tests.

Definite speed values for optimum shelling performance are machine based. For instance, studies involving the use of a variable speed motor indicated that speeds of 180-200 rpm produce an output range of $240-250 \mathrm{~kg} / \mathrm{h}$ with a breakage rate of $10-14 \%$ in a pneumatic drum sheller (Bobobee, 2002). Analysis of shelling speeds in castor oil fruits showed that the machine performed best at $240 \mathrm{rpm}$ (Balami et al., 2012). The best performance for experiments conducted by Adedeji and Ajuebor (2002) on groundnut shelling was achieved at 260 $\mathrm{rpm}$ and $150 \mathrm{~kg}$ (pods)/h feed rate. In carrying out in-field groundnut shelling tests, Butts et al. (2009) utilized a cylinder rotating within a range of $160 \mathrm{rpm}-300 \mathrm{rpm}$.

In this research experiments have been done to determine speed levels that yield optimum shelling efficiency, kernel mechanical damage and throughput per unit power consumption in a motorised groundnut sheller.

\subsection{Sheller Design Formulae}

In the design and development of a sheller, several quantitative models can be employed in sizing various parts. Following is a description of formulae for a groundnut sheller as provided by Akcali (1996) and Khurmi and Gupta (2009).

\subsubsection{Motor Power Rating}

Power requirement is determined using the following expressions;

$$
\begin{gathered}
P_{r}=a_{0}+a_{1} \frac{R_{1}}{R_{2}}\left(1-K_{Y}\right) \rho_{b g} \\
F=P_{r} A \\
T=F R(2.4) P_{S}=\frac{2 \pi N T}{60} \\
P_{m}=\frac{P_{S}}{\text { system efficiency } * \text { motor efficiency }}
\end{gathered}
$$

Where; $P_{r}=$ pressure exerted, $a_{0}=$ pressure strain coefficient at the surface of the beater

$a_{1}=$ pressure strain coefficient, $R_{1}=$ radius of the beater

$R_{2}=$ the radius of the concave from the centre of the beater, 
and approximated as;

$$
R_{2}=R_{1}+\beta_{s}
$$

Where;

$\beta_{s}=$ average pod size,

$$
\begin{gathered}
\rho_{b g}=\text { bulk density of groundnuts } \\
K_{Y}=\frac{\text { shelled groundnut weight }}{\text { input groundnut pods weight }}
\end{gathered}
$$

$A=$ surface area in contact with shelling blades in one revolution

$\mathrm{F}=$ Cracking force

$\mathrm{T}=$ Torque required

$\mathrm{R}=$ radius of beater

$\mathrm{P}_{\mathrm{s}}=$ Power transmitted by the shelling shaft and

$\mathrm{P}_{\mathrm{m}}=$ Motor Power requirement.

For groundnuts, $a_{0}=2.4$ and $a_{l}=10.1$ (Nyaanga et al., 2007)

\subsubsection{Pulley and Belt Formulae}

$$
\begin{gathered}
\frac{N_{1}}{N_{2}}=\frac{d_{2}}{d_{1}} \\
L=\pi\left(r_{1}+r_{2}\right)+2 x+\frac{\left(r_{1}-r_{2}\right)^{2}}{x}
\end{gathered}
$$

Where;

$N_{l}=$ Speed in rpm of pulley 1

$N_{2}=$ Speed in rpm of pulley 2

$d_{1}=$ Diameter of pulley 1

$d_{2}=$ Diameter of pulley 2

$r_{l}=$ Radius of pulley 1

$r_{2}=$ Radius of pulley 2

$x=$ Centre distance between pulley 1 and 2

$L=$ Length of belt connecting pulley 1 and 2 .

\subsubsection{Shaft Diameters}

Shaft diameters are determined by the following formulae; According to Guest's theory,

$$
T_{e}=\sqrt{\left(M_{\text {max }}\right)^{2}+\left(T_{\text {torq }}\right)^{2}}=\frac{\pi \tau d^{3}}{16}
$$

while the expression for Rankin`s theory is:

$$
=\frac{1}{2}\left\{M_{\max }+\sqrt{\left(M_{\max }{ }^{2}+T_{\text {torq }}{ }^{2}\right)}\right\}=\frac{\pi \sigma d^{3}}{32}
$$

Where;

$T_{e}=$ equivalent twisting moment

$\mathrm{Me}=$ equivalent bending moment

$M_{\max }=$ maximum bending moment on shaft

$T_{\text {torq }}=$ torque acting on the shaft,

And

$$
T_{\text {torq }}=\left(T_{1}-T_{2}\right) R
$$

Where;

$T_{1}=$ tension in the tight side of belt

$T_{2}=$ tension in the slack side of the belt
$R=$ radius of the pulley

$\boldsymbol{\tau}=$ allowable shear stress of the shaft material

$\sigma=$ allowable normal stress of the shaft material

$d=$ diameter of the shaft

\section{Research Methodology}

Design of the groundnut sheller was accomplished using equations 2.2 to 2.13 in the literature review section.

\subsection{Shelling Shaft Speed}

The design began with selection of a desired output of shelled kernels per unit time. A kernel throughput of $200 \mathrm{~kg} / \mathrm{h}$ was deemed adequate for experimental purposes and translates into shelling of $500 \mathrm{~kg}$ kernels in 2.5 hours, an amount equivalent to the average Kenyan groundnut yield per hectare as indicated in the introduction section. Determination of shelling shaft speed, $\mathrm{N}_{\mathrm{ss}}$, in revolutions per minute (rpm) was done by considering groundnut characteristics of volume and both bulk and solid densities of pods, kernels and shells. In addition, the width of the sieve in the shelling chamber was set to enable computation of the volume of pods shelled per revolution. The formula used was as follows;

$$
N_{s S}=\frac{\text { Volume of shelled pods per minute }}{\text { Volume of shelled pods per rev.*cracking efficiency }}
$$

$\mathrm{N}_{\mathrm{ss}}$ was determined as $350 \mathrm{rpm}$.

\subsubsection{Power Requirement}

First, pressure $(\mathrm{P})$ exerted in shelling was calculated using formula 2.2. Now, for groundnuts, $a_{0}=2.4, a_{1}=10.1, R_{1}=$ $0.2 \mathrm{~m}, \boldsymbol{\beta}_{S}=0.0126 \mathrm{~m}, R_{2}=0.2126 \mathrm{~m}, K_{Y}=2 / 3$ and $\rho_{b g}$ $=172.44 \mathrm{~kg} / \mathrm{m}^{3}$; resulting in $P=548.54 \mathrm{~N} / \mathrm{m}^{2}$. Cracking force per revolution, F, was determined by applying formula 2.3, while contact area (A) was computed as shown below;

$$
\mathrm{A}=C_{1 / 2} w n_{c}
$$

Where:

$C_{1 / 2}=$ half circumference of shelling cylinder

$w=$ width of sieve

$n=$ number of shelling blades

$w n_{c}=$ cracking efficiency

Contact area was determined as $0.424 \mathrm{~m}^{2}$. Determined values of $\mathrm{P}$ and $\mathrm{A}$ were inserted in formulae 2.4 to 2.6 , and system and motor efficiencies of $75 \%$ and $80 \%$ respectively applied. This results yielded motor power capacity of $2.84 \mathrm{Kw}$ (equivalent to $3.8 \mathrm{hp}$ ). A motor with a power rating of $4.4 \mathrm{hp}$ was deemed adequate.

\subsubsection{Pulley Sizes}

Pulley sizes were determined by using the velocity ratio formula 2.9. Diameter of pulley on shelling shaft was set as $500 \mathrm{~mm}$ while that of pulley on motor shaft as $125 \mathrm{~mm}$. The dimensions of the intermediate pulleys were varied according to the shelling speeds desired. 


\subsubsection{Shaft Diameters}

Shaft diameters were determined by applying the equivalent twisting moment formulae 2.11 and 2.12. The diameter of fan shaft was computed as $25 \mathrm{~mm}$ while that of the sheller shaft as $35 \mathrm{~mm}$. The resultant dimensions of the major machine components are shown in Table 3.1.

Table 3.1. Dimensions of sheller components.

\begin{tabular}{lllllll}
\hline $\begin{array}{l}\text { Shelling blades } \\
\text { radius }(\mathbf{m m})\end{array}$ & $\begin{array}{l}\text { Concave radius } \\
(\mathbf{m m})\end{array}$ & $\begin{array}{l}\text { Motor power } \\
\text { rating }(\mathbf{h p})\end{array}$ & $\begin{array}{l}\text { Shelling shaft } \\
\text { pulley diameter } \\
(\mathbf{m m})\end{array}$ & $\begin{array}{l}\text { Motor shaft pulley } \\
\text { diameter }(\mathbf{m m})\end{array}$ & $\begin{array}{l}\text { Fan shaft diameter } \\
(\mathbf{m m})\end{array}$ & $\begin{array}{l}\text { Shelling shaft } \\
\text { diameter }(\mathbf{m m})\end{array}$ \\
\hline 200 & 213 & 4.4 & 500 & 125 & 25 & 35 \\
\hline
\end{tabular}

\subsection{Sheller Performance}

Groundnuts were made ready for experiments by sorting and cleaning by hand-removal of defective pods and unwanted materials like soil and stone particles. The nuts were then dried in sunlight to a moisture content of $6 \%$. For each experiment unit, the following quantities were measured: Test run time, $\mathrm{T}(\mathrm{s})$; Weight of shelled seeds per unit time at main outlet, $\mathrm{W}_{\mathrm{b}}(\mathrm{kg} / \mathrm{h})$;

Weight of shelled seeds per unit time at chaff outlet, $\mathrm{W}_{\mathrm{c}}$ $(\mathrm{kg} / \mathrm{h})$; Weight of unshelled seed per unit time at all outlets, $\mathrm{W}_{\mathrm{d}}(\mathrm{kg} / \mathrm{h})$; Weight of damaged seeds per unit time at all outlets $\mathrm{W}_{\mathrm{e}}(\mathrm{kg} / \mathrm{h})$ and electric power consumed during the test, $\mathrm{P}$ (kWh).

Performance of the sheller was determined by following formulae:

Total throughput per unit time;

$$
\mathrm{W}_{\mathrm{a}}=\mathrm{W}_{\mathrm{b}}+\mathrm{W}_{\mathrm{c}}+\mathrm{W}_{\mathrm{d}}(\mathrm{kg} / \mathrm{h})
$$

Shelling efficiency;

$$
E_{S}=\left(1-\frac{W_{d}}{W_{a}}\right) * 100 \%
$$

Kernel Mechanical damage;

$$
E_{D}=\left(\frac{W_{e}}{W_{a}} * 100\right) \%
$$

Throughput per unit power consumed;

$$
E_{P}=\frac{W_{a}}{P}(\mathrm{Kg} / \mathrm{h}) / \mathrm{kWh}
$$

\subsection{Experiment Design and Setup}

\subsubsection{Influence of Groundnut Characteristics on Sheller Performance}

\section{(i). Moisture Content}

Each variety of groundnuts was divided into five equal portions. To obtain nuts at moisture contents of about $18 \%$, $15 \%, 12 \%, 9 \%$ and $6 \%$, four batches were soaked in water for a period of 20,15, 10 and 5 minutes respectively and spread out in natural air for 8 hours before storing them in labeled polybags ready for subsequent experiments. The fifth batch was not soaked in water, thus retaining a moisture content of $6 \%$. Moisture content levels were determined using a moisture meter.

A known weight of groundnuts at $18 \%$ moisture content was shelled at pre-set levels of variety, feed rate, shelling speed, concave clearance and sheller blade type. The time taken for the shelling process was determined by a stop clock. The weights of shelled, unshelled and damaged seeds at various machine outlets were measured by means of a weighing balance. Electric power consumed by the motor was determined by a watt meter connected to its cable. The experiment was repeated to obtain three replicates. The procedure for the next four levels of experiments was similar to the one already described except that the moisture contents of the nuts used were $15 \%, 12 \%, 9 \%$ and $6 \%$ respectively.

\section{(ii). Variety}

Five different varieties of groundnuts were chosen to represent the range of sizes available in the research site. The following were selected for this purpose: ICGV 99658, ICGV 9991, CG 7, Homa bay local and Valencia red. In the first set of experiments, ICGV 99658 of known weight was shelled at pre-set levels of moisture content, feed rate, concave clearance, shelling speed and shelling blades type. The remaining four varieties were used in the next four sets of experiments respectively. A replication of three was applied for all the experiments.

\section{(iii). Feed Rate}

A sliding gate in the form of a rectangular plate fitted on one of the slanting surfaces of the trapezoidal hopper was used to regulate feed rate. A fixed weight of groundnuts was shelled at various gate positions and the corresponding feed rates in $\mathrm{kg} / \mathrm{h}$ recorded. The positions on the rectangular plate at which the feed rates of $400 \mathrm{~kg} / \mathrm{h}, 800 \mathrm{~kg} / \mathrm{h}, 1200 \mathrm{~kg} / \mathrm{h}, 1600 \mathrm{~kg} / \mathrm{h}$ and $2000 \mathrm{~kg} / \mathrm{h}$ were attained were identified by use of a marker pen. The five levels of feed rates were then used in experiments for this section.

In the first set of experiments, a fixed quantity of groundnuts was shelled at a feed rate of $400 \mathrm{~kg} / \mathrm{h}$ at pre-set levels of moisture content, variety, shelling speed, concave clearance and shelling blades type. Computation of sheller performance was done as described in section 3.2. The second, third, fourth and fifth sets of experiments were carried out in a similar manner to the first one but at feed rates of $800 \mathrm{~kg} / \mathrm{h}$, $1200 \mathrm{~kg} / \mathrm{h}, 1600 \mathrm{~kg} / \mathrm{h}$ and $2000 \mathrm{~kg} / \mathrm{h}$ respectively.

\subsubsection{Influence of Machine Characteristics on Sheller Performance}

\section{(i). Shelling Speed}

From literature review, motorised shellers are commonly run at shaft speeds of between $160 \mathrm{rpm}$ and $400 \mathrm{rpm}$. Five speed levels for experimental purposes were chosen as 150 $\mathrm{rpm}, 250 \mathrm{rpm}, 350 \mathrm{rpm}, 480 \mathrm{rpm}$ and $580 \mathrm{rpm}$. The selected 
shaft speeds were attained by mounting pulleys available on the Kenyan market with a diameter range of $100 \mathrm{~mm}$ to 250 $\mathrm{mm}$ interchangeably on the two ends of the fan shaft. Belts of appropriate lengths were utilized to transmit power from the fan shaft to the shelling shaft. Velocity ratio and belt length formulae were used to calculate the diameter and lengths of the required pulleys and belts for experiments in this section.

Actual speeds during operation were measured by use of a tachometer. Five levels of experiments were carried out in this section with a replication of three for each. In the first level, a specified weight of groundnuts were shelled at a shaft speed of $150 \mathrm{rpm}$ and at selected levels of moisture content, variety, feed rate, concave clearance and shelling blades type. In the second, third, fourth, and fifth levels of experiments, shaft speeds of $250 \mathrm{rpm}, 350 \mathrm{rpm}, 480 \mathrm{rpm}$ and $580 \mathrm{rpm}$ were applied respectively.

Tangential velocity changes proportionally with radius of the shelling blades for a given constant angular speed. Hence, there is need to determine the corresponding tangential velocities for the shaft speeds to obtain the shelling speeds for the blades. The following formulae were used;

$$
v=w r
$$

And

$$
w=\frac{2 \pi N}{60}
$$

Where:

$v=$ tangential velocity

$w=$ angular velocity

$r=$ shelling blade radius

$N=$ shaft speed in revolutions per minute

Using equations 3.7 and 3.8, Table 3.2 was obtained.
Table 3.2. Shelling speeds.

\begin{tabular}{ll}
\hline Shaft speed, $\boldsymbol{N}(\mathbf{r p m})$ & Tangential shelling speed, $\boldsymbol{v}(\mathbf{m} / \mathbf{s})$ \\
\hline 150 & 3.2 \\
250 & 5.3 \\
350 & 7.4 \\
480 & 10.1 \\
580 & 12.2 \\
\hline
\end{tabular}

\section{(ii). Concave Clearance}

Concave clearance was determined by measuring the distance between the shelling blades and the concave sieve at the point where the clearance was at a minimum.

\section{(iii). Shelling Blade Type}

Five types of blades were employed in experiments under this section. The first type was made of iron paddles having a curved shape of radius $200 \mathrm{~mm}$, thickness of $2 \mathrm{~mm}$, length of $420 \mathrm{~mm}$ and a distance of $32 \mathrm{~mm}$ along the circumference. The second type was similar to the first but with the paddles covered with strips of rubber. Thirdly; steel pipes acted as the shelling blades. The thickness of the pipes was $2 \mathrm{~mm}$ with a diameter of $10 \mathrm{~mm}$. The fourth type was similar to the third but with an extra circumscribed pipe free to roll around its axis. The fifth type consisted of steel pipes covered with rubber strips.

\subsubsection{Factor Level Combinations for Optimum Sheller Performance}

The characteristics whose influence on sheller performance were investigated together with their selected factor levels are shown in Table 3.3

\begin{tabular}{|c|c|c|c|c|c|c|}
\hline \multirow[b]{2}{*}{$\begin{array}{l}\text { Level } \\
\text { number }\end{array}$} & \multicolumn{6}{|c|}{ Nut and machine characteristics } \\
\hline & $\begin{array}{l}\text { Moisture } \\
\text { content (\%) }\end{array}$ & Groundnut variety & Feed rate $(\mathrm{Kg} / \mathrm{h})$ & $\begin{array}{l}\text { Shelling speed } \\
(\mathrm{m} / \mathrm{s})\end{array}$ & $\begin{array}{l}\text { Concave } \\
\text { clearance } \\
(\mathrm{mm})\end{array}$ & Shelling blades type \\
\hline 1 & 6 & ICGV 99658 & 400 & 3.2 & 10 & Steel paddle \\
\hline 2 & 9 & ICGV 9991 & 600 & 5.3 & 15 & Rubber paddle \\
\hline 3 & 12 & CG 7 & 1200 & 7.4 & 20 & Fixed steel pipe \\
\hline 4 & 15 & Homa bay local & 1600 & 10.1 & 25 & Rolling rubber pipe \\
\hline
\end{tabular}

Table 3.3. Selected levels of nut and machine characteristic.

In this section determination of combined influence of all the six charateristics on sheller performance at different combination levels was carried out. A Taguchi experiment design with an orthogonal array L25(56) was set up to obtain results for all experiments outlined in section 3.3 and is depicted in Table 3.4.

\begin{tabular}{|c|c|c|c|c|c|c|}
\hline Experiment No. & $\begin{array}{l}\text { Shelling speed } \\
(\mathrm{m} / \mathrm{s})\end{array}$ & Shelling blade type & $\begin{array}{l}\text { Groundnut } \\
\text { variety }\end{array}$ & $\begin{array}{l}\text { Moisture } \\
\text { content (\%) }\end{array}$ & $\begin{array}{l}\text { Feed rate } \\
(\mathrm{kg} / \mathrm{h})\end{array}$ & Concave clearance $(\mathrm{mm})$ \\
\hline 1 & 3.2 & Steel paddle & 99658 & 6 & 400 & 10 \\
\hline 2 & 3.2 & Rubber paddle & 9991 & 9 & 800 & 15 \\
\hline 3 & 3.2 & Steel pipe & CG 7 & 12 & 1200 & 20 \\
\hline 4 & 3.2 & Rubber pipe & Homa bay & 15 & 1600 & 25 \\
\hline 5 & 3.2 & Rolling pipe & Valencia & 18 & 2000 & 30 \\
\hline 7 & 5.3 & Rubber paddle & $\mathrm{CG} 7$ & 15 & 2000 & 10 \\
\hline
\end{tabular}

Table 3.4. Taguchi experiment design with an orthogonal array L25(56). 


\begin{tabular}{lllllll}
\hline Experiment No. & $\begin{array}{l}\text { Shelling speed } \\
(\mathbf{m} / \mathbf{s})\end{array}$ & Shelling blade type & $\begin{array}{l}\text { Groundnut } \\
\text { variety }\end{array}$ & $\begin{array}{l}\text { Moisture } \\
\text { content (\%) }\end{array}$ & $\begin{array}{l}\text { Feed rate } \\
\text { (kg/h) }\end{array}$ & Concave clearance (mm) \\
\hline 8 & 5.3 & Steel pipe & Homa bay & 18 & 400 & 15 \\
9 & 5.3 & Rubber pipe & Valencia & 6 & 800 & 20 \\
10 & 5.3 & Rolling pipe & 99658 & 9 & 1200 & 25 \\
11 & 7.4 & Steel paddle & CG 7 & 18 & 800 & 25 \\
12 & 7.4 & Rubber paddle & Homa bay & 6 & 1200 & 30 \\
13 & 7.4 & Steel pipe & Valencia & 9 & 1600 & 10 \\
14 & 7.4 & Rubber pipe & 99658 & 12 & 2000 & 15 \\
15 & 7.4 & Rolling pipe & 9991 & 15 & 400 & 20 \\
16 & 10.1 & Steel paddle & Homa bay & 9 & 2000 & 20 \\
17 & 10.1 & Rubber paddle & Valencia & 12 & 400 & 25 \\
18 & 10.1 & Steel pipe & 99658 & 15 & 800 & 30 \\
19 & 10.1 & Rubber pipe & 9991 & 18 & 1200 & 10 \\
20 & 10.1 & Rolling pipe & CG 7 & 6 & 1600 & 15 \\
21 & 12.2 & Steel paddle & Valencia & 15 & 1200 & 15 \\
22 & 12.2 & Rubber paddle & 99658 & 18 & 1600 & 20 \\
23 & 12.2 & Steel pipe & 9991 & 6 & 2000 & 25 \\
24 & 12.2 & Rubber pipe & CG 7 & 9 & 400 & 30 \\
25 & 12.2 & Rolling pipe & Homa bay & 12 & 800 & 10 \\
\hline
\end{tabular}

Optimization of performance was achieved at the combination levels that gave the highest values of throughput per unit power consumption and shelling efficiency; and lowest value of kernel mechanical damage.

\subsection{Data Analysis}

The influence of a single factor on a performance parameter was determined by computing the average output values at each factor level and the results obtained analyzed graphically. Analysis for combined factor influences was done using signal-to-noise $(\mathrm{S} / \mathrm{N})$ ratio techniques. $\mathrm{S} / \mathrm{N}$ values were calculated for all the experiment trials using mathematical expressions according to Wysk et al. (2000). The following formula was applied for calculating $\mathrm{S} / \mathrm{N}$ for kernel mechanical damage (the smaller, the better);

$$
S /_{N}=-10 \log \left[\frac{1}{n} \sum_{i=1}^{n} y_{i}^{2}\right]
$$

$\mathrm{S} / \mathrm{N}$ values for throughput per unit power consumption and shelling efficiency (the larger, the better), were determined as;

$$
S / N=-10 \log \left[\frac{1}{n} \sum_{i=1}^{n} \frac{1}{y_{i}^{2}}\right]
$$

Where;

$n=$ number of experiment replications in a trial and $y_{i}=\mathrm{i}^{\text {th }}$ measured output value for the trial.

Mean $\mathrm{S} / \mathrm{N}$ values were determined for each factor level with the highest value corresponding to the optimum desired output. Output response graphs were plotted from these results to show the influence of the factors under investigation on performance of the sheller. In addition, significance of influence of factors on performance was determined by carrying out an analysis of variance (ANOVA) on the $\mathrm{S} / \mathrm{N}$ ratios obtained. Confirmation experiments were then conducted to verify the performance of the optimum conditions as determined by the matrix experiment.

\section{Research Findings}

\subsection{Moisture Content}

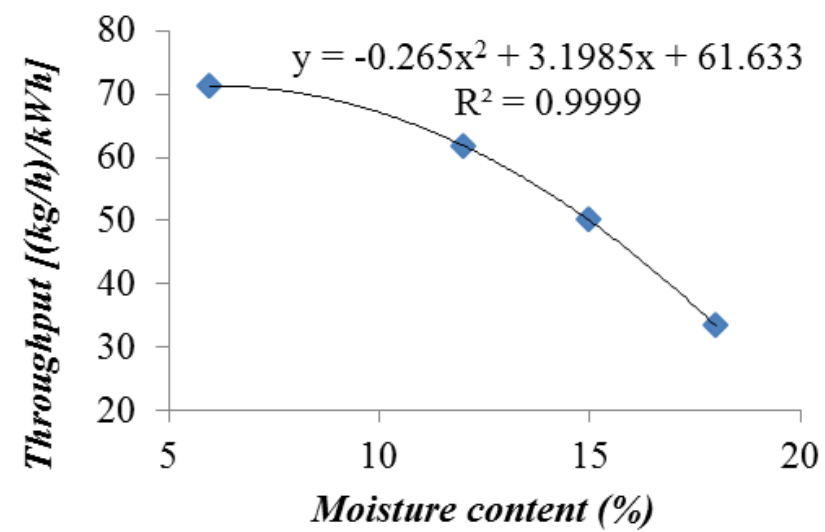

Figure 4.1. Throughput and moisture content.

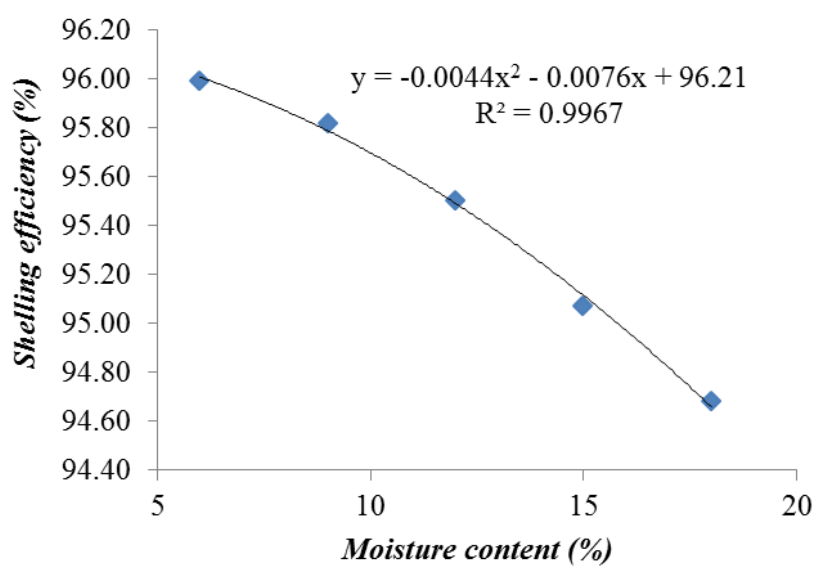

Figure 4.2. Shelling efficiency with moisture content. 


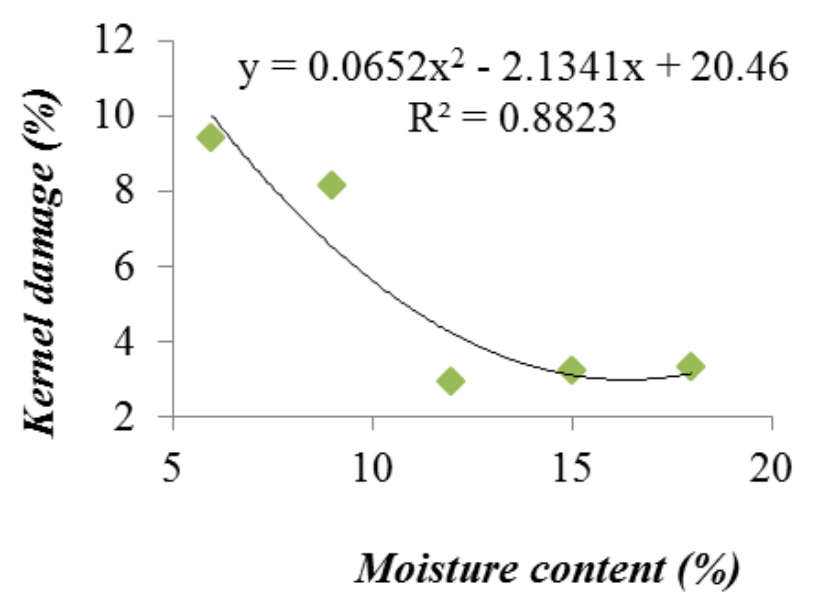

Figure 4.3. Kernel damage and moisture content.

Figure 4.1, 4.2 and 4.3 show how groundnut moisture content influenced throughput per unit power consumption, shelling efficiency and kernel mechanical damage respectively. The graphs were plotted from results for various experiments as shown in Appendix C.

The results show that machine throughput per unit power consumption increased with decrease in groundnut moisture content. This could be explained by the fact that the dry pods were more brittle than the wet ones, hence, they fractured faster upon being subjected to impact and frictional forces during the shelling process. As such, fewer motor revolutions were required to achieve complete shelling of a given quantity of groundnut pods with less moistutre content. The highest throughput per unit power consumption was achieved at $6 \%$ moisture content.

Shelling efficiency was also found to increase with reduction in moisture content with the highest efficiency being realised at $6 \%$ moisture content. The explanation for influence of moisture content on throughput per unit power consumption explained above also holds true for shelling efficiency. According to Nyaanga et al. (2007), pods with higher moisture content tend to flex instead of cracking and breaking hence leading to a higher percentage of unshelled groundnuts.

It was observed that kernel mechanical damage was highest at the lowest moisture content of about $6 \%$, minimum at moisture contents between $15 \%$ and $18 \%$ and then increased marginally with further increase in moisture content. At a lower moisture content, the high brittleness of the kernels lends them to increased breakage. On the other hand, damage of kernels with very high moisture content was observed to occur by way of splitting along their middle axis. This could be attributed to a decrease in seed mechanical strength as explained by Gamal et al. (2008).

\subsection{Groundnut Vareiety}

The following varieties of groundnuts were used to carry out tests under this section; ICGV 99658, ICGV 9991, CG 7, Homa bay local and Valencia red and are shown in plate 4.2.

They were chosen to represent a wide spectrum of pod and kernel physical characteristics such as size, density and repose angle. The results of their influence on sheller performance are shown graphically in Figures 4.4 to 4.6.

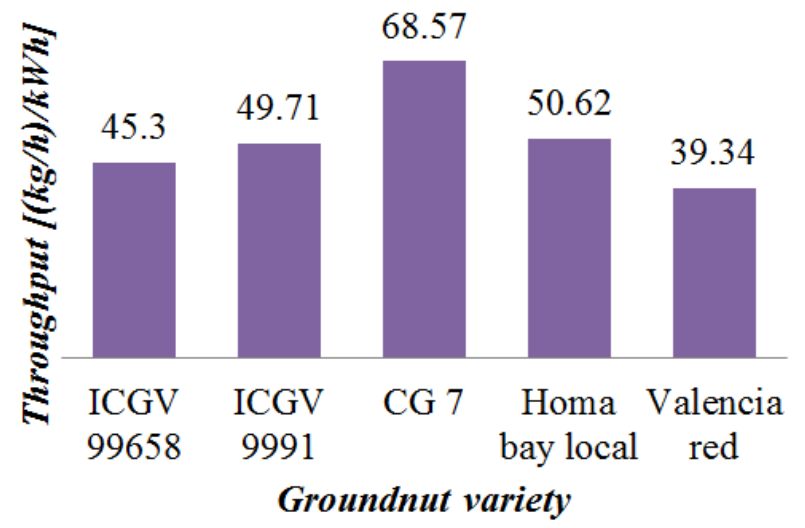

Figure 4.4. Throughput and nut variety.

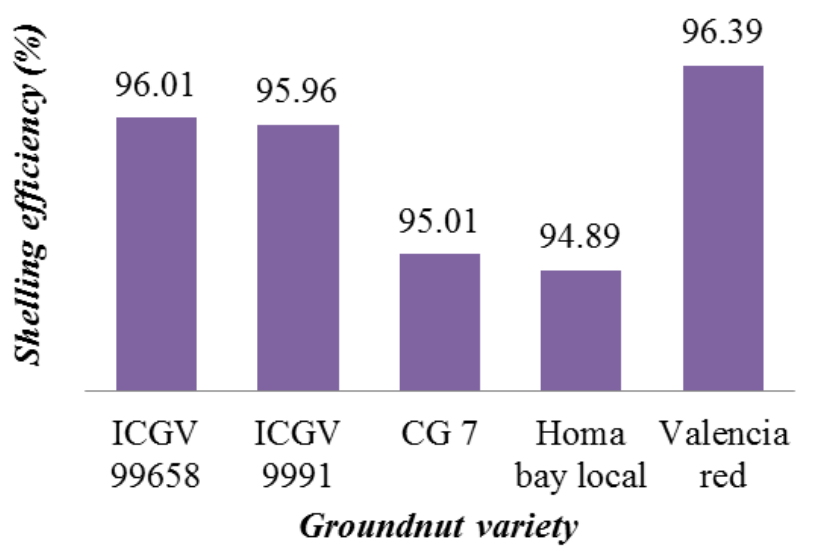

Figure 4.5. Shelling efficiency with nut variety.

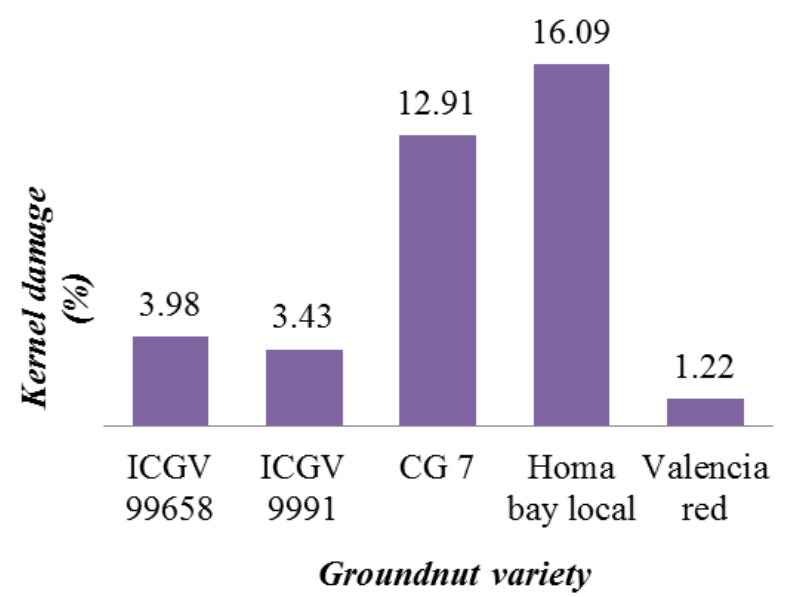

Figure 4.6. Kernel damage and nut variety.

The results show that variety CG 7 yielded the highest throughput per unit power consumption while Valencia red the lowest. It can also be seen from Figure 4.5 and 4.6 that the influence of the varieties under investigation on shelling efficiency and kernel mechanical damage follow the same pattern. Thus, Valencia red, ICGV 9991 and ICGV 99658 
resulted in both high shelling efficiency and low kernel mechanical damage while CG 7 and Homa bay local led to low shelling efficiency and high kernel mechanical damage when shelled.
Experiments were carried out on several physical characteristics of groundnut varieties under study in a bid to explain the observations observed above. The results are shown in Table 4.1.

Table 4.1. Physical characteristics for selected groundnut varieties.

\begin{tabular}{|c|c|c|c|c|c|}
\hline Variety & $\begin{array}{l}\text { Pod bulk density } \\
\left(\mathrm{kg} / \mathrm{m}^{3}\right)\end{array}$ & Kernel bulk density $\left(\mathrm{kg} / \mathrm{m}^{3}\right)$ & $\begin{array}{l}\text { Pod size (major diameter) } \\
(\mathrm{mm})\end{array}$ & $\begin{array}{l}\text { Kernel size (major } \\
\text { diameter) }(\mathrm{mm})\end{array}$ & $\begin{array}{l}\text { Kernel:Pod diameter } \\
\text { ratio }\end{array}$ \\
\hline CG 7 & 301.16 & 616.11 & 12.54 & 9.91 & 0.7903 \\
\hline Homa bay local & 297.53 & 615.54 & 13.46 & 9.87 & 0.7332 \\
\hline ICGV 99658 & 212.43 & 639.46 & 12.65 & 9.27 & 0.7328 \\
\hline ICGV 9991 & 245.60 & 662.27 & 12.20 & 7.68 & 0.6295 \\
\hline Valencia red & 224.56 & 673.61 & 13.00 & 7.46 & 0.5738 \\
\hline
\end{tabular}

It can be infered from the results that throughput per unit power consumption increased with pod bulk density of the variety of groundnuts being shelled. Thus, variety CG 7 with the highest pod bulk density of $301.16 \mathrm{~kg} / \mathrm{m}^{3}$ had the highest throughput per unit power consumption while ICGV 99658 with the lowest pod bulk density of $212.43 \mathrm{~kg} / \mathrm{m}^{3}$ had the second last lowest throughput per unit power consumption.

Groundnut kernel to pod diameter ratio proved to be a vital characteristic as far as shelling efficiency and kernel mechanical damage are concerned. Results in Table 4.1 show that a high ratio translated into a low shelling efficiency and a high kernel mechanical damage. Following is a possible explanation for this scenario; A low kernel to pod diameter ratio corresponds to a wider air space between the husk and the kernel. This makes it relatively easier for the kernels to be released when the pods are fractured and they are less prone to impact and frictional forces occasioned by the rotating shelling blades. In addition, kernel mechanical damage rose with increase in kernel size. A large sized kernel, being heavier, collides with the fast moving shelling blades with greater momentum than a small one making it more vulnerable to cracking or splitting during the shelling process.

\subsection{Shelling Speed}

Shelling speeds ranging from $3.2 \mathrm{~m} / \mathrm{s}$ to $12.2 \mathrm{~m} / \mathrm{s}$ were employed in tests done under this section and the results obtained are as shown in the following figures;

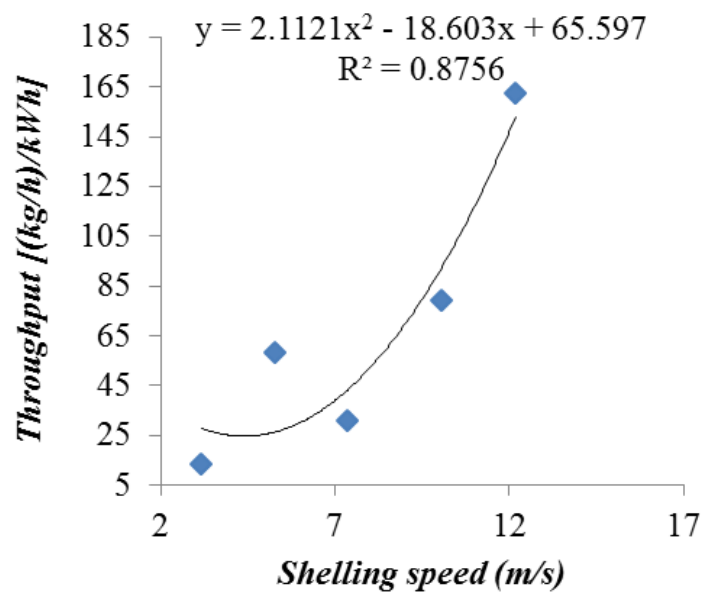

Figure 4.7. Throughput with shelling speed.

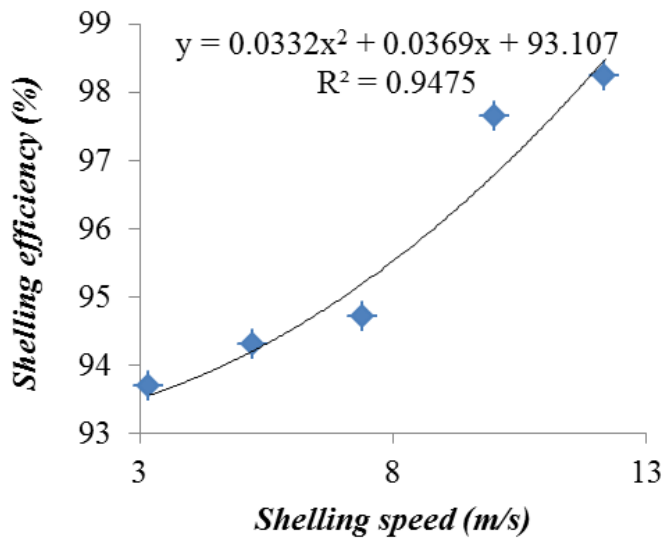

Figure 4.8. Shelling efficiency and shelling speed.

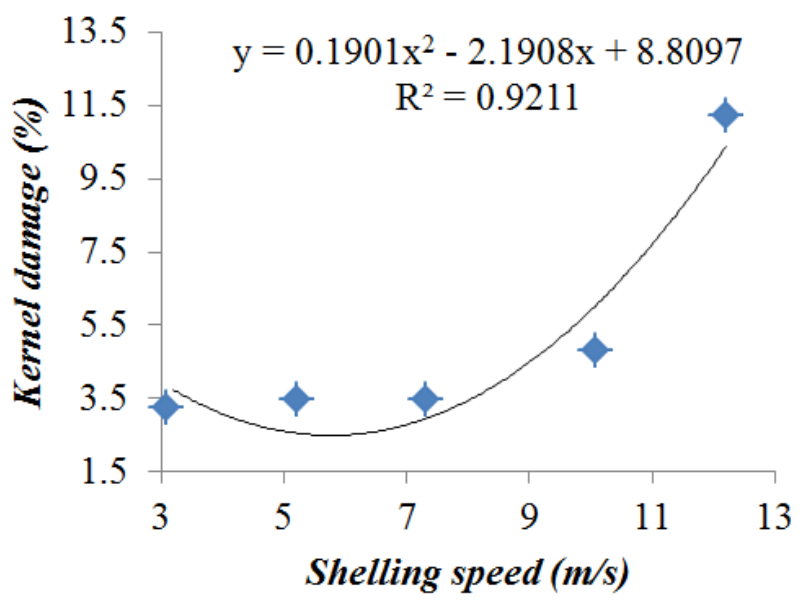

Figure 4.9. Kernel damage and shelling speed.

From Figure 4.10 and 4.11, both throughput per unit power consumption and shelling efficiency rose with increase in shelling speed with the highest values obtained around $12 \mathrm{~m} / \mathrm{s}$ for this set of experiments. Figure 4.12 shows that kernel mechanical damage remained below $4 \%$ for all speeds below $8 \mathrm{~m} / \mathrm{s}$ then rose sharply with further increase in speed.

The collision and rubbing actions that generate the forces that result in the shelling of the groundnut pods; as well as the momentum of the shelling blades, increase with raise in shelling speed. This would lead to an increase in throughput per unit power consumption, shelling efficiency and kernel mechanical damage. 


\subsection{Concave Clearance}

Five concave clearance levels of $10 \mathrm{~mm}, 15 \mathrm{~mm}, 20 \mathrm{~mm}$, $25 \mathrm{~mm}$ and $30 \mathrm{~mm}$ were used to obtain the results that generated the graphs shown in Figure 4.10 to 4.12.

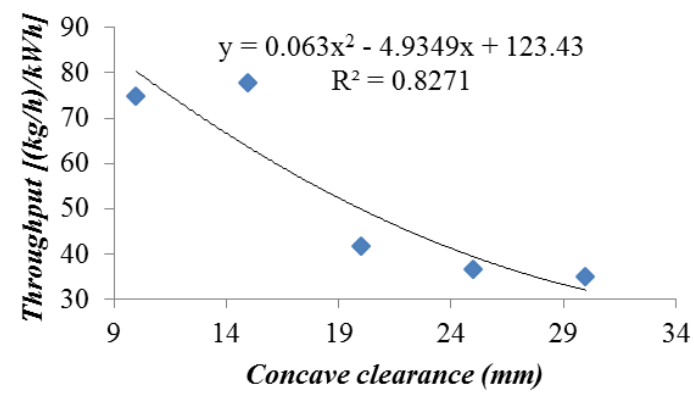

Figure 4.10. Throughput with concave clearance.

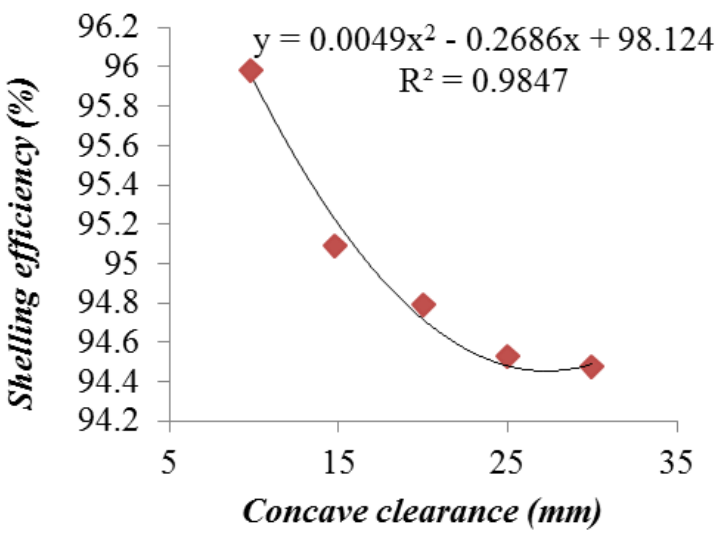

Figure 4.11. Shelling efficiency with concave clearance.

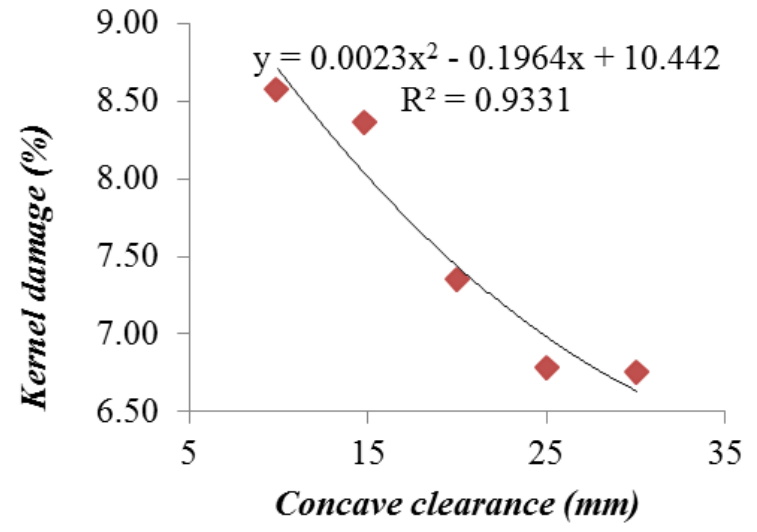

Figure 4.12. Kernel damage and concave clearance.

From the figures, throughput per unit power consumption, shelling efficiency as well as kernel mechanical damage decreased with increase in concave clearance. This arose from the fact that at low concave clearance the groundnut pods are most compact and when subjected to impact and frictional forces during the shelling process, they are likely to fracture or open more easily leading to the high values of throughput per unit power consumption and shelling efficiency but this also resulted in high kernel mechanical damage.

The factor combinations that yielded the three optimum output performance, according to the mean $\mathrm{S} / \mathrm{N}$ ratios and response graphs above, are as outlined in Table 4.2.

Table 4.2. Factor level combination for optimum groundnut sheller performance.

\begin{tabular}{|c|c|c|c|c|c|c|}
\hline \multirow{2}{*}{$\begin{array}{l}\text { Groundnut sheller } \\
\text { performance outputs }\end{array}$} & \multicolumn{6}{|c|}{ Optimum groundnut and machine factor combinations } \\
\hline & $\begin{array}{l}\text { Shelling speed } \\
(\mathrm{m} / \mathrm{s})\end{array}$ & $\begin{array}{l}\text { Shelling blade } \\
\text { type }\end{array}$ & $\begin{array}{l}\text { Groundnut } \\
\text { variety }\end{array}$ & $\begin{array}{l}\text { Moisture content } \\
(\%)\end{array}$ & $\begin{array}{l}\text { Feed rate } \\
(\mathrm{kg} / \mathrm{h})\end{array}$ & $\begin{array}{l}\text { Concave clearance } \\
(\mathrm{mm})\end{array}$ \\
\hline $\begin{array}{l}\text { Throughput per unit power } \\
\text { consumption }\end{array}$ & 12.2 & Rubber paddle & CG 7 & 6 & 1600 & 10 \\
\hline Shelling efficiency & 12.2 & $\begin{array}{l}\text { Rolling steel } \\
\text { pipe }\end{array}$ & Valencia red & 6 & 1600 & 10 \\
\hline Kernel mechanical damage & 7.4 & $\begin{array}{l}\text { Fixed rubber } \\
\text { pipe }\end{array}$ & Valencia red & 12 & 800 & 15 \\
\hline
\end{tabular}

\subsubsection{Factor Significance}

Significance of individual factors in influencing overall performance was determined by carrying out an analysis of variance (ANOVA) at $0.1(\alpha=0.1)$ level of significance on the
$\mathrm{S} / \mathrm{N}$ values of the three output parameters. The results are contained in Tables C8 to $\mathrm{C} 10$ in the Appendix section with a summary shown in Table 4.3

Table 4.3. Factor percentage contribution.

\begin{tabular}{|c|c|c|c|c|c|c|}
\hline \multirow[b]{2}{*}{ Output parameter } & \multicolumn{6}{|c|}{ Factor contribution Factor contribution (\%) (\%) } \\
\hline & Moisture content & Nut variety & Feed rate & $\begin{array}{l}\text { Shelling } \\
\text { speed }\end{array}$ & $\begin{array}{l}\text { Concave } \\
\text { clearance }\end{array}$ & $\begin{array}{l}\text { Shelling blade } \\
\text { type }\end{array}$ \\
\hline Throughput per unit power consumed & 6.94 & 3.16 & 6.90 & 67.94 & 11.64 & 3.42 \\
\hline Shelling efficiency Shelling efficiency & 19.91 & 16.48 & 16.05 & 8.22 & 20.53 & 13.20 \\
\hline Kernel mechanical damage & 31.02 & 36.56 & 5.08 & 6.24 & 12.11 & 3.31 \\
\hline
\end{tabular}

Results from the three ANOVA tables led to several conclusions. First, shelling speed contributed most to the 
combined factor influence on throughput per unit power consumption, at $67.94 \%$, while groundnut variety was the least significant at $3.16 \%$. Secondly, the individual percentage contribution of the factors towards influence on shelling efficiency lay between $8.22 \%$ (shelling speed) and $20.53 \%$ (concave clearance). Hence, they were, approximately, equally significant. Lastly, kernel mechanical damage was mostly influenced by two factors; groundnut variety $(36.56 \%)$ and moisture content $(31.02 \%)$, the rest of the factors posting contributions of $12.11 \%$ and below.

\subsubsection{Optimal Outputs}

Table 4.4. Expected optimum outputs.

\begin{tabular}{lll}
\hline Performance parameter & Optimum s/n ratio & Expected optimum outpts \\
\hline Throughput per unit power consumption & 63.13 & $985.14(\mathrm{~kg} / \mathrm{h}) / \mathrm{kWh}$ \\
Shelling efficiency & 40.36 & $104.23 \%$ \\
Kernel mechanical damage & 3.15 & $0.7 \%$ \\
\hline
\end{tabular}

Actual outputs were determined by carrying out confirmation experiments at the optimal factor levels outlined

in Table 4.4 above. Results obtained for the actual optimal outputs are shown in Table 4.5

Table 4.5. Actual optimum outputs.

\begin{tabular}{|c|c|c|c|c|c|c|c|c|}
\hline \multicolumn{6}{|c|}{ Groundnut and machine factor combinationbination groundnut } & \multicolumn{3}{|l|}{ Outputs } \\
\hline $\begin{array}{l}\text { Shelling } \\
\text { speed }(\mathrm{m} / \mathrm{s})\end{array}$ & Shelling blade type & $\begin{array}{l}\text { Groundnut } \\
\text { variety }\end{array}$ & $\begin{array}{l}\text { Moisture } \\
\text { content } \\
(\%) \\
\end{array}$ & $\begin{array}{l}\text { Feed rate } \\
(\mathrm{kg} / \mathrm{h})\end{array}$ & $\begin{array}{l}\text { Concave } \\
\text { clearance } \\
(\mathbf{m m}) \\
\end{array}$ & $\begin{array}{l}\text { Throughput per unit } \\
\text { power consumption } \\
{[(\mathrm{Kg} / \mathrm{h}) / \mathrm{kWh}]}\end{array}$ & $\begin{array}{l}\text { Shelling } \\
\text { efficiency } \\
(\%) \\
\end{array}$ & $\begin{array}{l}\text { Kernel } \\
\text { mechanical } \\
\text { damage }(\%)\end{array}$ \\
\hline 12.2 & Rubber paddle & CG 7 & 6 & 1600 & 10 & $921.03 *$ & 97.38 & 52.15 \\
\hline 12.2 & Rolling steel pipe & Valencia red & 6 & 2000 & 10 & 178.80 & $99.08 *$ & 8.08 \\
\hline 7.4 & Fixed rubber pipe & Valencia red & 12 & 800 & 15 & 92.13 & 96.75 & $1.25^{*}$ \\
\hline
\end{tabular}

*= Optimum values for each output parameter

A comparison of the theoretical and the actual optimum outputs shows that the two sets of values were close to each other. Experiments carried out under this study applied batch feeding mechanism, in which an average weight of $7 \mathrm{~kg}$ of in-pod groundnuts was shelled for each test run. Continuous feeding mechanism is often practiced under field conditions.
Hence, an extra experiment, employing continuous feeding mechanism was conducted at factor level setting for optimum kernel damage, in which $140 \mathrm{~kg}$ of in-pod groundnuts was fed into the sheller. Table 4.6 shows a comparison of the two set of results that were obtained.

Table 4.6. Output results for batch and continuous feeding mechanisms.

\begin{tabular}{llll}
\hline \multirow{2}{*}{ Feeding mechanism } & $\begin{array}{l}\text { Throughput per unit power consumption } \\
{[(\mathrm{Kg} / \mathrm{h}) / \mathrm{kWh}]}\end{array}$ & $\begin{array}{l}\text { Shelling efficiency } \\
(\%)\end{array}$ & $\begin{array}{l}\text { Kernel mechanical damage } \\
(\%)\end{array}$ \\
\hline Continuous & 495.23 & 96.57 & 2.02 \\
Batch & 92.13 & 96.75 & 1.25 \\
\hline
\end{tabular}

It can be inferred from the results that continuous loading of in-pod groundnuts into the feed hopper yielded a much higher throughput per unit power consumption than batch feeding but with an accompanied slight increase in kernel damage. Shelling efficiency remained relatively constant.

\section{Conclusions and Recommendations}

Results obtained from this study show that the groundnut and machine characteristics considered influenced throughput per unit power consumption, shelling efficiency and kernel mechanical damage to various levels. Throughput per unit power consumption and shelling efficiency increased with reduction in $\%$ moisture content of the groundnut pods, with maximum outputs realized at $6 \%$ mc. Kernel mechanical damage decreased with increase in $\% \mathrm{mc}$ up to a minimum at between $15 \%$ and $18 \%$ mc then increased marginally with further rise in moisture content.

Meanwhile, throughput per unit power consumption increased with bulk density of the groundnut variety being shelled. Thus, variety CG 7 being heaviest yielded the greatest throughput per unit power consumed. In addition, kernel to pod diameter ratio had a significant influence on the outputs under study. Varieties with a higher kernel to pod diameter ratio like CG 7, resulted in lower shelling efficiency and higher kernel mechanical damage than those with a lower kernel to pod diameter ratio such as Valencia red.

All the three output parameters under review rose exponentially with increase in feed rate.

Throughput per unit power consumption and shelling efficiency rose steadily with increase in shelling speed with the highest values obtained at a shelling speed of about $12 \mathrm{~m} / \mathrm{s}$. On the other hand, kernel mechanical damage remained low (less than $4 \%$ ) for speeds below $8 \mathrm{~m} / \mathrm{s}$, and then rose sharply with further increment in speed.

It was observed that all the output parameters increased with reduction in concave clearance with maximum values obtained at $10 \mathrm{~mm}$ clearance.

The conclusion concerning the influence of shelling blade type on output parameters was as follows; Steel and rubber 
paddles yielded the highest throughput per unit power consumption. At low shelling speeds (less than $8 \mathrm{~m} / \mathrm{s}$ ), rolling rubber and steel pipes resulted in lowest shelling efficiency and kernel mechanical damage but at higher speeds they resulted into both highest shelling efficiency and kernel mechanical damage.

The following are recommendations for further research: Influence of shelling blade type on performance outputs, yielded inconclusive results. The influence of machine factors on groundnut sheller performance can include sieve type and size. Research can be done to determine groundnut and machine factor combinations that result in optimum winnowing efficiency amongst motorised groundnut shellers

\section{References}

[1] Abubakar, M., and Abdulkadir, B. H. (2012). Design and Evaluation of a Motorised and Manually Operated Groundnut Shelling Machine. International Journal of Emerging Trends in Engineering and Development, 4(2): 673-682.

[2] Adedeji, O. S., and Ajuebor, F. N. (2002). Performance Evaluation of Motorised Groundnut Sheller. Journal of Agricultural Engineering, 39(2): 53-56.

[3] Akcali, I. D., Ince, A., and Guzel, E. (2006). Selected Physical Properties of Groundnuts. International Journal of Food Properties, 9(1): 25-37.

[4] Amoah, F. (2012). Modification and Evaluation of a Groundnut Cracker for Cracking Jatropa curcus Seeds. Unpublished Master`s Thesis, Kwame Nkrumah University of Science and Technology, Department of Agricultural Engineering.

[5] Amadu, N. (2012). Development and Performance Evaluation of an Improved Soybean Thresher. Unpublished Master's Thesis, Ahmadu Bello University, Zaria Nigeria, Department of Agricultural Engineering.

[6] Anantachar, M., Maurya, N. L., and Navaravani, N. B. (1997). Development and Performance Evaluation of Pedal Operated Decorticator. Journal of Agricultural Sciences, 10(4): 1078-1081.

[7] Armitage, D., and Wontner-Smith, T. (2008). Grain moisture-Guidelines for Measurement. HGCA-Funded Project, Caledonia House 223 Petronville Road London NI9HY.

[8] Aslan, N., and Cebeci, Y. (2006). Application of Box-Behnken Design and Response Surface Methodology for Modeling of some Turkish Coals. Cumhuriyet University, Mining Engineering Department, Turkey.

[9] Atiku, A., Aviara, N., and Haque, M. (2004). Performance Evaluation of a Bambara Groundnut Sheller. Agricultural Engineering International, the CIGR journal of Scientific Research and Development, 6(Manuscript PM 04 002): 1-18.

[10] Balami, A. A., Adgidzi, D., Kenneth, C. A., and Lamuwa, G. (2012). Performance Evaluation of a Dehusking and Shelling Machine for Castor Fruits and Seeds. Journal of Engineering (IOSR JEN), 2(10): 44-48.

[11] Ballal, Y. P., Inamdar, K. H., and Patil, P. V. (2012). Application of Taguchi Method for Design of Experiments in Turning Gray Cast Iron. International journal of Engineering Research and Application (IJERA), 2(3)): 1391-1397.
[12] Bhatia, A. (2010). Pneumatic Conveying Systems.

[13] Unpublished lecture notes, Course No. M05-010 Continuous Education and Development, Inc; 9 Creyridge Farm Court, Story Point, NY 10980.

[14] Bobobee, E. (2002). No more Fingertip Shelling: The TEK groundnut Cracker to the Rescue; The International Journal of Small-scale Food Processing, 30: 12-15.

[15] Butts, C. L., Sorenseen, R. B., Nuti, R. C., Lamb, M. C., and Faircloth, W. H. (2009). Performance of Equipment for In-field Shelling of Groundnut for Biodiesel Production. American Society of Agricultural and Biological Engineers, 52(5): 1461-1469.

[16] Chinsuwan Winit (1983). Groundnut Shellers Project (Thailand) (File No. 3-80-0128, April, 1981-March, 1983). Submitted to International Development Research Centre (IDRC), Khon Kaen University, Department of Agriculture Engineering.

[17] Delhagen, W., Hussam, S., Mohdramli, R., and Alexander, Y. (2003). A Low-cost Groundnut Sheller for Use in Developing Nations.

[18] Duke, D., and Joyashree, R. (2011). Approach to Energy Efficiency among Micro, Small and Medium Enterprises in India. A field survey.

[19] Gamal, E., Radwan, S., ElAmir, M., and ElGamal, R. (2009). Investigating the Effects of Moisture Content on some Properties of Groundnut by aid of Digital Image Analysis. Food and Bio products Processing, 87: 273-281.

[20] Gitau, A. N., Mboya, P., Njoroge, B. K., and Mburu, M. (2013). Optimizing the Performance of a manually Operated Groundnut (Arachis hypogaea) Decorticator. Open Journal of Optimization, 2(1)): 26-32.

[21] Gitu, K. W., and Nzuma, J. M. (2003). Data Compendium for Kenya`s Agricultural Sector; Kenya Institute of Public Policy Research and Analysis (KIPPRA)(Special Report, February 2003), Nairobi, Kenya.

[22] Helmy, M. A., Mitrroi, A., Abdallah, S. E., and Basioury, M. A. (2007). Modification and Evaluation of a Reciprocating Machine for Shelling Groundnut. Misr Journal of Agricultural Engineering, 24(2): 283-298.

[23] Henderson, S. M., and Perry, R. L. (1976). Agricultural Process Engineering. Westport, Connecticut: The AVI Publishing Company.

[24] Ikechukwu, C. U., Olawale, J. O., and Ibukun, B. I. (2014). Design and Fabrication of Groundnut Shelling and Separating Machine. International Journal of Engineering Science Invention, 3(4): 60-66.

[25] Ishola, T. A., Oni, K. C., Yahya, A., and Abubakar, M. S. (2011) Development and Testing of a Prosopis Africana Pod Thresher. Australian Journal of Basic and Applied Sciences, 5(5): 759-767.

[26] Kamboj, P., Singh, A., Kumar, M., and Din, S. (2012). Design and Development of Small Scale Pea Depoding Machine by using CAD Software. Agricultural Engineering International: CIGR Journal, 14(2): 40-48.

[27] Karuga, S., and Alfred, K. (2010). Staple Foods Value Chain Analysis- Country Report-Kenya. 
[28] Khurmi, R. S., and Gupta, J. K. (2009). A Textbook of Machine Design $\left(14^{\text {th }}\right.$ ed.). Ram Nagar, New Delhi: Eurasia Publishing House.

[29] Palomar, M. K. (1998). Groundnut in the Philippines Food System (A Macro Study, Groundnut in Local and Global Food Systems Series Report No. 1), University of Georgia, Department of Anthropology.

[30] Madhusudhana, B. (2013). A Survey on Area, Productivity of Groundnut Crop in India. IOSR Journal of Economics and Finance, 1(3): 1-7.

[31] Mezarcioz, S. M., and Ogulata, T. R. (2011). The Use of Taguchi Design of Experiment Method in Optimizing Spirality Angle of Single Jersey Fabrics. Texstil ve Konfeksiyon, 4(2011): 374-380.

[32] Nyaanga, D. M., Chemeli, M. C., and Wambua, R. M. (2007). Development and Testing of a Portable Hand-Operated Groundnut Sheller. Egerton Journal, 7(S): 117-130.

[33] Park, H. J., Cho, Y. K., Hong, S. G., and Song, C. J. (1990). Study on the development of a groundnut sheller for seed. Journal: Research Reports of the Rural Development Administration, Farm Management, Agricultural Engineering and Sericulture, 32(1): 61-67.

[34] Rai, A. K., Kottayi, S., and Murty, S. N. (2005). A low Cost Field Usable Portable Grain Moisture Meter with Direct
Display of Moisture (\%). African Journal of Science and Technology (AJST), Science and Engineering Series, 6(1): 97-104.

[35] Rostami, M. A., Azadshahraki, F., and Najafinezhad, H. (2009). Design, Development and Evaluation of a Groundnut Sheller. Journal: AMA, Agricultural Mechanization in Asia, Africa and Latin America, 40(2): 47-49.

[36] Siebenmorgan, T. J., Jia, C., Qin, G., and Schluterman. (2006). Evaluation of Selected Rice Laboratory Shelling Equipment. American Society of Agricultural and Biological Engineers, 22(3): 427-430.

[37] Simonyan, K. J., and Yiljep, Y. D. (2008). Investigating Grain Separation and Cleaning Efficiency Distribution of a Conventional Stationary Rasp-bar Sorghum Thresher. Agricultural Engineering International: the CIGR Ejournal, 10(Manuscript PM 07 028): 1-13.

[38] Tetsuro, T., and Shozo, K. (2010). Using IT to Eliminate Energy Waste in Production Lines. (Yokogawa Technical Report, English Edition, Vol.53, No.1).

[39] Thompson, M. (2009). Experimental Design and Optimization (3): Some Fractional Factorial Designs; AMCTB No. 36.

[40] Wysk, R. A., Niebel, B. W., Cohen, P. H., and Simpson, T. W. (2000). Manufacturing Processes: Integrated Product and Process Design. McGraw Hill, New York. 